\title{
A Reforma da Missa por Martin Lutero: princípios para o fazer litúrgico no contexto brasileiro 500 anos depois
}

\author{
The Reform of the Mass by Martin Luther: \\ principles for the liturgical praxis in the Brazilian context \\ 500 years later
}

Júlio Cézar Adam

\section{Resumo}

Este artigo pretende retomar os aspectos que determinaram a compreensão de culto na Reforma com base em Martin Lutero e refletir sobre estas concepções e princípios da Reforma para o culto cristão de hoje, principalmente no contexto brasileiro, com seus desafios litúrgicos, mas também sociais. Para tanto, o artigo fará uma investigação bibliográfica considerando as produções sobre o tema do contexto brasileiro e, a partir dos principais textos de Lutero a respeito tanto da realidade litúrgica da Reforma, como as propostas litúrgicas deixadas pelo reformador. O artigo está organizado em três partes. Na primeira parte, apresenta-se o contexto social da época da Reforma, bem como o contexto eclesial e do culto cristão. Em seguida, trata-se da reforma litúrgica da missa desenvolvida por Lutero, concentrando-se, em especial, na Formula Missae (1523) e na Deutsche Messe (1526). No último ponto do artigo, como conclusão, apresenta-se alguns princípios para a reflexão e a práxis litúrgico para o contexto brasileiro atual.

Palavras-chave: Reforma. Liturgia. Culto Cristão. Brasil 


\begin{abstract}
This article intends to take up the aspects that determined the understanding of worship in the Reform based on Martin Luther and to reflect on these conceptions and principles of the Reforma for the Christian worship today, in the Brazilian context, with its liturgical as well as social challenges. For this, the article will make a bibliographical investigation considering the productions on the theme of the Brazilian context and, from the main texts of Luther regarding both the liturgical reality of the Reformation and the liturgical proposals left by the reformer. The article is organized in three parts. The first part presents the social context of the Reform period, as well as the ecclesial context and of the Christian worship. Next, it is addressed the liturgical reform of the mass developed by Luther, focusing in particular on the Formula Missae (1523) and the Deutsche Messe (1526). In the last point of the article, as a conclusion, are presented some principles for liturgical reflection and praxis are presented for the current Brazilian context.
\end{abstract}

Keywords: Reform. Liturgy. Christian worship. Brazil

\title{
Introdução
}

Considerando que um ano tem 52 domingos, em 500 anos uma comunidade apenas, celebrou em torno de 26 mil cultos. Apenas uma comunidade! Imaginemos somar todas as comunidades oriundas da Reforma, quantos milhares de culto foram celebrados. Estes milhares de cultos, porém, tem a mínima relevância diante do Culto de Deus prestado a nós: a cruz de Jesus Cristo. Todos os milhares de cultos dos 500 anos de permanente reforma são apenas reverberações daquilo que sempre de novo Deus faz a nós em e através de Jesus Cristo, a justificação por graça, recebida por nós na fé e respondida apenas e unicamente por meio da fé, manifestada também em forma de culto e louvor. Este é o princípio básico para entender aquilo que define o culto que irá se desenvolver a partir da Reforma. Não se trata de um culto luterano ou um culto calvinista ou com qualquer outro adjetivo, mas sim, da missa reformada, o culto cristão evangélico, justamente por se fundamentar no princípio evangélico, na ação de Jesus Cristo. 
Refletir sobre a Reforma e o culto significa, portanto, levar a sério este princípio, evitando assim o risco de transformar a reflexão de Lutero sobre o culto em uma norma, uma lei, algo que Lutero nunca quis. Nos últimos dois anos tem se falado muito a respeito da Reforma, por conta das reflexões e comemorações em torno aos 500 anos desse movimento. Por detrás de todo este entusiasmo, em si, muito importante, há quase um risco de se idealizar a Reforma como se nela estivesse contido uma fórmula ou uma norma da reta doutrina e prática pura da Igreja, também no que se refere ao culto e à liturgia. Ouve-se, inclusive, a ideia de que voltar a Lutero é uma forma de resgate de uma fonte segura para enfrentar a transitoriedade e relativismo dos tempos hipermodernos (G. Lipovetsky). Nem Lutero, nem a Reforma pretenderam ser esta norma canônica, normativa e conclusiva. No caso do culto, como já apontado acima, nem mesmo existe um culto luterano, como tal. Se há algo luterano na liturgia é a liturgia que por dois mil anos foi sendo gestada e celebrada na Igreja.

A reflexão litúrgica que embasa a renovação litúrgica experimentada na Igreja Evangélica de Confissão Luterana no Brasil (IECLB), buscou, justamente transpor os 500 anos de Reforma. Ou seja, seguindo esse princípio reformatório e luterano, se busca entender aquilo que constitui o culto cristão além da própria Reforma, buscando inspiração e, acima de tudo, princípios teológicos e litúrgicos, na vasta tradição que remonta especialmente às primeiras comunidades cristãs dos três primeiros séculos, confirmando aquilo que tão bem James F. White sintetizou: “a descoberta de nossas raízes nos deu asas". Este foi o movimento realizado por muitas igrejas e denominações, tanto a Igreja Católica Apostólica Romana, através do Movimento Litúrgico, anterior ao Concílio Vaticano II, como por igrejas protestantes, entre elas as luteranas, a partir do século XX. Volta-se às origens do culto cristão, entendendo que a proximidade de Jesus Cristo é critério de legitimidade para qualquer movimento de reforma ou renovação litúrgica na atualidade. Infelizmente esse critério, tão coerente com a própria Reforma, não é entendido por muitas igrejas oriundas desse movimento, inclusive por parte dos ditos "luteranos".

É interessante, ainda, observar a escassez de reflexão sobre o culto e a Reforma em nosso contexto. Além de obras traduzidas, como o Manual de Ciência Litúrgica, ${ }^{1}$ do contexto evangélico alemão, e materiais traduzidos da

\footnotetext{
${ }^{1}$ SCHMIDT-LAUBER, H.-C.; BIERITZ, K.-H.; MEYER-BLANCK, M. (Eds.)., Manual de Ciência Litúrgica, v.1; SCHMIDT-LAUBER, H.-C.; BIERITZ, K.-H.; MEYER-BLANCK, M. (Eds.)., Manual de Ciência Litúrgica, v.2; SCHMIDT-LAUBER, H.-C.; BIERITZ, K.-H.;
} 
Federação Luterana Mundial (FLM), ${ }^{2}$ além dos materiais litúrgico interno das igrejas, como manuais de culto e ofícios (jornal evangélico), existem poucas reflexões no contexto brasileiro sobre o culto e liturgia com base na reforma luterana. ${ }^{3}$ A reflexão sobre culto em Lutero que considero mais completa e profunda é a feita pelo teólogo Romeu R. Martini, em sua tese doutoral, publicada com o título Eucaristia e Conflitos Comunitários, em 2003. ${ }^{4}$ Além disso, há um pequeno texto escrito por Ricardo W. Rieth, na Revista Tear, do ano de 2002. ${ }^{5}$ Mais recentemente temos a publicação, resultado do $3^{\circ}$ Simpósio Internacional de Lutero, Lutero e o culto cristão. ${ }^{6}$ Não se pode esquecer ainda os aportes sobre o culto luterano no contexto brasileiro, na obra clássica de Hahn, História do culto protestante no Brasil, de 1989.7 Outras reflexões relevantes, são escassas. Por isso, este estudo é importante.

$\mathrm{O}$ artigo, portanto, faz uma revisão de aspectos que determinaram a compreensão de culto na Reforma de Lutero, refletindo sobre possíveis consequências para o culto cristão de hoje, em especial no contexto brasileiro, com seus desafios litúrgicos, mas também sociais e políticos. O artigo faz uma investigação bibliográfica considerando as produções do contexto brasileiro e, principalmente, a partir dos principais textos de Lutero a respeito tanto da realidade litúrgica da Reforma, como as propostas litúrgicas elaboradas por Lutero. Importante ressaltar que este artigo não pretende apresentar um estudo sobre a prática litúrgica de igrejas luteranas no contexto brasileiro, mas sim, refletir sobre princípios teológicos do fazer litúrgico a partir da reforma de Lutero. Com base nessa reflexão, pretende-se pensar algumas consequências para o culto de hoje em nosso contexto.

MEYER-BLANCK, M. (Eds.)., Manual de Ciência Litúrgica, v.3; SCHMIDT-LAUBER, H.-C.; BIERITZ, K.-H.; MEYER-BLANCK, M. (Eds.)., Manual de Ciência Litúrgica, v.4.

${ }^{2}$ FLM. O culto luterano; BRAND, E. (Ed.)., A liturgia entre os luteranos; FLM., Declaração de Caracas sobre liturgia.

${ }^{3} \mathrm{O}$ recente publicado Radicalizando a Reforma, que reúne diferentes abordagens sobre a Reforma no contexto Latino Americano, não tem sequer uma abordagem sobre culto e pregação, aspectos fundamentais para entender a Reforma no nosso contexto: HOFFMANN, M.; BEROS, D.; MOONEY, R. (Ed.)., Radicalizando a Reforma.

${ }^{4}$ MARTINI, R. R., Eucaristia e conflitos comunitários, p. 195-283.

${ }^{5}$ RIETH, R. W., Lutero e o culto cristão, p. 7-8.

${ }^{6}$ BUSS, P. W. (Org.)., Lutero e o culto cristão.

${ }^{7} \mathrm{HAHN}$, C. J., História do culto protestante no Brasil. 


\section{Contexto litúrgico da Reforma}

A Reforma Protestante iniciada a exatamente 500 anos atrás revolucionou a Igreja e o mundo da sua época e o culto foi um dos palcos principais onde as ideias da Reforma ganharam expressão. A questão das indulgências, a compreensão de obra e de sacrifício, o papel da pregação como expressão da viva vox Evangelii, as mudanças no entendimento da Eucaristia, a função do sacerdote, o canto e a música, entre tantos outros elementos e aspectos, tudo estava de alguma maneira relacionado ao culto, uma vez que é no culto onde essas mudanças hermenêuticas e teológicas ganham expressão.

Mesmo assim, não é possível dizer que a Reforma Luterana significou uma revolução no âmbito do culto e da liturgia. Em termos litúrgicos, a concepção de culto luterana é conservadora e uma das que mais manteve a continuidade com a grande tradição litúrgica da Igreja, como irá dizer Lethrop, com base em outros estudos. A Reforma Luterana é a "reforma conservadora" (Krauth), a "rebelião obediente" (Pelikan) e a "catolicidade evangélica" (Wiggermann) ${ }^{8}$ Sem sombra de dúvidas, pode-se afirmar que a compreensão de culto do luteranismo é marcada pelo conservadorismo e pela crítica, como tão bem descreve Lathrop.

A abordagem do culto sempre foi marcada pela pronta recepção da grande tradição litúrgica cristã e, conjugadamente, de igual modo por certas tendências conservadoras na prática local concreta. Ao mesmo tempo, porém, também pertence à abordagem luterana uma crítica vigilante da tradição e a disposição de reordenar seus elementos, de descartá-los ou acentuá-los de modo diferente, sempre que a "clareza do Evangelho" de Jesus Cristo na celebração comunitária parecia exigi-lo. ${ }^{9}$

Sabe-se que Teologia e Liturgia sempre se influenciam mutuamente, de modo que toda teologia desemboca em uma determinada liturgia e viceversa. No caso da Reforma não foi diferente. Pode-se dizer que a dinâmica "lex orandi e lex credendi", ou seja, a maneira como oramos e rendemos culto terá efeito na maneira como cremos, é importante para entender o movimento desencadeado por Lutero e suas consequências no culto. ${ }^{10}$ No

\footnotetext{
${ }^{8}$ LATHROP, G. W., O culto no contexto luterano, p. 220.

${ }^{9}$ LATHROP, G. W., O culto no contexto luterano, p. 220.

${ }^{10}$ WAINRIGHT, G., Fundamentação sistemático-teológica, p. 126ss.
} 
caso do legado de Lutero em relação ao culto, talvez pode-se dizer, que muito mais a lex credendi irá influenciar a lex orandi, ou seja, a mudança hermenêutica de Lutero, principalmente sua compreensão da Palavra, do Evangelho desde a perspectiva paradigmática da justificação por graça e fé, como algo dinâmico na vida da pessoa e da comunidade definirá a reforma do culto. Este princípio protestante irá trazer mudanças sobre a maneira de entender e reformar a missa católica e o culto evangélico, como veremos a seguir. Ou seja, o culto refletirá, como um espelho, as mudanças em curso na teologia bíblica, sistemática, em especial na eclesiologia e, no que hoje chamamos de teologia prática.

Pensemos um pouco mais o contexto mais amplo da Reforma. Sabe-se que a Reforma não surge isoladamente com Lutero. Ela é resultado de um amplo processo que envolveu pessoas de diferentes tempos e locais, como bem conhecido é o caso de João Huss (1373-1415), alguns séculos antes do movimento da Alemanha. A Reforma é resultado de um amplo e dinâmico movimento que envolveu homens e mulheres, a exemplo de Katarina von Bora, conhecidos e anônimos. Quando Lutero prega as 95 teses na porta do castelo de Wittenberg, as insatisfações e críticas à igreja, bem como às autoridades seculares, se intensificaram. No âmbito econômico e social havia tensões, com o crescimento da população e uma clara divisão entre campo e cidade. Segundo Martini,

\begin{abstract}
[...] até o Final do século 15, a sociedade da Saxônia dividia-se em três categorias básicas: a maioria dos agricultores, uma pequena camada de nobres e uns poucos príncipes. Porém, com a efervescência econômica, essa divisão se alterou. Assim como nas cidades surgiu a classe dos burgueses, no campo, respectivamente, nas vilas, a antiga categoria dos agricultores também sofreu uma divisão. Enquanto algumas famílias ampliaram sua base econômica - trabalhavam na terra e na tecelagem, alugavam parte da sua casa para outros operários -, a grande parte delas empobreceu e caiu na dependência econômica. ${ }^{11}$
\end{abstract}

A Igreja Medieval agrava ainda mais esta situação, com sua teologia demasiadamente amparada na ameaça da punição de Deus e na culpa das pessoas, bem como na necessidade de comprar a salvação. De um culto marcado pela ação de graças da Igreja Primitiva anterior à institucionalização

${ }^{11}$ MARTINI, R. R., Eucaristia e conflitos comunitários, p. 201. 
de Constantino, no séc. IV (313 d.C.), o que temos na Igreja Medieval tardia é um culto baseado na penitência.

O culto da Igreja Medieval estava amparado no princípio escolástico de que seria possível ao ser humano conquistar o amor de Deus e a vida eterna através de um número suficientemente grande de boas obras. A venda de indulgências e a vida monástica se enquadram, pois, dentro desta compreensão. A vida monástica significava o melhor caminho para aquilo que a Igreja considerava o caminho de salvação, caminho que o próprio Lutero seguiu. As demais pessoas que não seguiam o ideal monástico cumpriam as exigências da Igreja e grande parte disso ocorria no e em torno do culto. ${ }^{12}$

A reforma protestante, partindo de redescoberta da hermenêutica evangélica da graça e da fé irá se concentrar de forma coerente em desfazer o caráter penitencial do culto e torná-lo novamente uma ação de graças, espaço para a vivência litúrgica do Evangelho. Podemos dizer que três grandes princípios da Reforma irão atingir diretamente a reforma que será feita no culto: a compreensão de Deus oriunda da doutrina da justificação por graça e fé; a compreensão de liberdade cristã e a compreensão da Palavra de Deus.

A justificação por graça e fé reverte o foco da ação. Não é mais a Igreja, o sacerdote e o crente que faz algo em direção a Deus, para conquistar a salvação, mas é tão somente Deus que em Jesus Cristo alcança o ser humano e o redime do pecado, tornando-o, assim, justificado, por meio da sua fé. Este princípio leva à doutrina da liberdade cristã, uma vez que, na economia da salvação, não são os ritos, as obras, os sacrifícios, o clero e as ordens, nem mesmo o próprio culto, os elementos relevantes, mas tão somente a fé em Jesus Cristo. No caso da liturgia, Lutero insiste na liberdade da comunidade para celebrar seu culto e evita transformar as ordens litúrgicas ou os próprios princípios da Reforma em lei.

No que se refere à compreensão de Palavra de Deus, Lutero a entende como algo vivo, que escapa às letras da Escritura. A Palavra é Cristo e seu Evangelho. Esta está encarnada nas Escrituras, por assim dizer e torna-se palavra viva, viva voz, no momento em que é pregada. Jesus Cristo é, portanto, o centro e o critério de toda a Palavra. Como diz N. Kirst, "Jesus Cristo é tudo o que Deus tem a dizer, e tudo o que Deus tem a dizer se articula em Jesus Cristo."13 Deus efetua tudo por meio desta sua palavra: "Sem a Palavra, o

\footnotetext{
${ }^{12}$ MARTINI, R. R., Eucaristia e conflitos comunitários, p. 204.

${ }^{13}$ KIRST, N., Rudimentos de Homilética, p. 11.
} 
Espírito Santo não opera a santidade dos cristãos, da igreja, da communio sanctorum; sem a Palavra não há unidade, sem a Palavra a Igreja fraqueja, sem a Palavra a igreja não pode servir de orientadora, pois a igreja é gerada pela Palavra, é alimentada pala Palavra, é fortalecida pela Palavra." 14 É por meio da Palavra, Cristo, que o ser humano pecador é justificado. Tudo isto acontece por meio da pregação e do culto.

\section{Reforma litúrgica da Missa desenvolvida por Lutero}

Os principais textos e documentos onde Lutero escreve explicitamente sobre orientações para o culto ou propõe liturgias para o culto datam dos anos de 1523 e 1526: as orientações litúrgicas para a comunidade de Leisnig e as recomendações litúrgicas da Formula Missae, ambas de 1523 e a Missa Alemã, de 1526. A grande maioria dos textos de Lutero vão se concentrar em tratar os sacramentos ${ }^{15} \mathrm{e}$, em especial o sacramento do altar, a Eucaristia, ${ }^{16} \mathrm{e}$ com menos acento, o batismo. ${ }^{17}$ Percebe-se, assim, que a grande preocupação recaía exatamente sobre a Eucaristia, onde a mudança da compreensão sacrificial centrada na ação do sacerdote, e a compreensão da graça, centrada na ação de Cristo, precisava ser trabalhada.

Como vimos acima, a reforma litúrgica, no que se refere à forma, é bastante conservadora. No que se refere, porém, ao conteúdo e o significado, há mudanças profundas. Podemos dizer que temos aqui muito mais considerações do reformador com base no princípio evangélico da graça e da liberdade cristã do que uma reforma litúrgica, propriamente dita. Além disso, em todo o processo de mudanças e recomendações há um princípio pedagógico de mudanças graduais na vida cúltica da comunidade. Primeiro ele pretendia livrar o povo da falsa fé em cerimônias e esclarecer os corações por meio da pregação da Palavra. Depois propor mudanças na forma de celebrar.

\footnotetext{
${ }^{14}$ DREHER, M. N., Igreja, Ministério, Chamado e Ordenação, p. 28.

${ }^{15}$ LUTERO, M., Sermões sobre os Sacramentos, p. 399-424.

${ }^{16}$ LUTERO, M., Um Sermão a respeito do Novo Testamento, p. 253-275; LUTERO, M., Um Sermão sobre o Venerabilíssimo Sacramento do Santo e Verdadeiro Corpo de Cristo e Sobre as Irmandades, p. 425-444; LUTERO, M., Da Santa Ceia de Cristo - Confissão, p. 217-375; LUTERO, M., Exortação ao Sacramento do Corpo e Sangue de Nosso Senhor, p. 222-254.

${ }^{17}$ LUTERO, M., O Manual do Batismo Traduzido para o Alemão - Revisado 1526, p. 209-221.
} 
Lutero pensava em três tipos de culto. A missa latina, reformulada na Formula Missae, deveria continuar existindo. Sua argumentação parte de pressupostos pedagógico e ecumênico. A juventude estudiosa teria a oportunidade de exercitar seu latim e participar do ofício divino em outros países. A Missa Alemã destinava-se à gente simples. Muitos dos participantes da missa não eram crentes, mas meros assistentes. Oficiada em língua alemã, deveria promover a fé e conquistar para a fé. Além dessas duas formas de culto, Lutero pensava ainda em uma terceira, "a autêntica ordem evangélica", destinada "àqueles que querem ser cristãos sinceramente e confessam o Evangelho em palavras e ações". ${ }^{18}$

Em seu texto escrito em resposta ao pedido da comunidade de Leisnig, "A Ordem do Culto na Comunidade", ${ }^{19}$ Lutero julga oportuno começar a celebrar a missa sob as duas espécies, o pão e o vinho. Além disso, o reformador trata da pregação da Palavra, das missas diárias e dominicais e da liturgia das horas, além dos cultos aos santos. "Ali teceu duras críticas à opressão a que estava submetida a Palavra de Deus e fez propostas para o culto matinal e para os cultos vespertinos que substituiriam as orações das horas. Conservou em sua sugestão a missa dominical. As missas diárias, porém, foram abolidas. Os cânticos usuais foram mantidos, eliminando-se aquelas partes que se referiam aos santos. Desapareciam as festas dos santos. A pregação passava a ser o elemento principal do culto. ${ }^{20}$

As propostas mais importantes, porém, para visualizar como Lutero vislumbrou o princípio evangélico em propostas litúrgicas, advém da Formula Missae e da Missa Alemã. Aqui descobrimos que Lutero é conservador. Não é um revolucionário litúrgico, mas um reformador. De modo algum ele teve interesse de eliminar a missa romana, mas buscou reforma-la. "Partindo do princípio da justificação por graça e fé, distingue em sua análise da missa romana três grupos de partes litúrgicas. Uma é eliminada, outra é tolerada e a terceira, aceita sem restrições. Tudo o que está relacionado com a concepção sacrificial é eliminado. Tolera, porém, o que não é produto do espírito evangélico, mas também não se the opõe, devendo, contudo, sofrer correções na pregação. Finalmente, mantém tudo o que procede de espírito cristão e

\footnotetext{
${ }^{18}$ DREHER, M., Missa Alemã e Ordem do Culto 1526, p. 175-176.

${ }^{19}$ LUTERO, M., A Ordem do Culto na Comunidade 1523, p. 66-69.

${ }^{20}$ DREHER, M., Culto, p. 153.
} 
que foi transmitido sem deturpações". ${ }^{21}$ Importante para ele é que não se transforme o culto e a liturgia em lei, algo que contradizia frontalmente o princípio evangélico.

A Formula Missae ou Formulário da Missa e da Comunhão para a Igreja de Wittenberg foi dirigia ao reformador de Zwickau e Dessau, Nicolau Hausmann, no final de 1523, quem tantas vezes lhe havia pedido uma forma evangélica para celebrar. No prefácio ao formulário, Lutero deixa claro o princípio restaurador da missa. "Nem agora nem jamais foi nossa intenção abolir totalmente todo o culto a Deus, mas apenas purificar novamente esse que está em uso, mas que está viciado pelos piores acréscimos, e mostrar o uso evangélico". ${ }^{22}$ Lutero entende que a missa é a comunhão no pão e no vinho divinamente instituída no tempo de Cristo e no tempo apostólico. Os pais da Igreja acrescentaram elementos em torno a este núcleo básico da missa, o que o reformador considera louvável, como os cantos dos salmos e introito, o Kyrie eleison, o Gloria in excelsis, leituras das epístolas e dos Evangelhos, aleluia, o Credo Niceno, o prefácio, o Sanctus, Agnus Dei e comunhão ${ }^{23}$, podendo ser utilizados ou não. O problema, segundo ele, ocorre quando a missa começa a se tornar um sacrifício, acrescentando-se os ofertórios e as coletas mercenárias, tornando-se monopólio sacerdotal, em favor de defuntos, de viajantes, por prosperidade. ${ }^{24}$ Com base no princípio evangélico, a missa é dádiva e ação de Deus, recebida pela pessoa e pela comunidade, por meio da fé, celebrada como ação de graças por aquilo que Deus fez e faz por meio de Cristo. O nome, pouco importa desde que o princípio da graça de Deus esteja garantido. "Nós a compreendemos como sacramento, testamento, ação de graças, como se diz em latim, ou eucaristia em grego, mês do Senhor, Ceia do Senhor, memória do Senhor, comunhão, ou qualquer nome evangélico que agrade, desde que a designação não esteja poluída pela idéia de sacrifício ou obra". ${ }^{25}$ Partindo do critério daquilo que consta na Escritura, Lutero irá considerar o Evangelho e a Eucaristia como fundamento do culto, sendo todos os demais elementos acessórios destes dois. ${ }^{26}$

\footnotetext{
${ }^{21}$ DREHER, M., Formulário da Missa e da Comunhão para a Igreja de Wittenberg 1523, p. 155.

${ }^{22}$ LUTERO, M., Ao em Cristo venerável Nicolau Hausmann, p. 157.

${ }^{23}$ LUTERO, M., Ao em Cristo venerável Nicolau Hausmann, p. 157s.

${ }^{24}$ LUTERO, M., Ao em Cristo venerável Nicolau Hausmann, p. 158s.

${ }^{25}$ LUTERO, M., Ao em Cristo venerável Nicolau Hausmann, p. 159.

${ }^{26}$ LUTERO, M., Ao em Cristo venerável Nicolau Hausmann, p. 161.
} 
Lutero pretendia com a manutenção da missa latina não só preservar o vínculo com a tradição da Igreja Antiga, mas propiciar que os jovens conhecessem e praticassem o latim. ${ }^{27} \mathrm{O}$ mais importante da Formula Missae é que os elementos sacrificiais foram eliminados. Mesmo assim, cresce o apelo de pastores e do próprio príncipe-eleito da Saxônia por uma liturgia em alemão. Já desde 1522, cidades e regiões estavam celebrando a Santa Ceia ou a missa em língua alemã, sem uma uniformidade litúrgica. ${ }^{28}$ Lutero dizia não se sentir competente para tal empreendimento, uma vez que precisava de bons conhecimentos musicais para que texto e música estivessem em sintonia. Em 1525 Lutero se lança à tarefa de tentar uniformizar as celebrações litúrgicas, da qual surge uma primeira proposta litúrgica. Conrado Ruppsch e Johann Walter irão auxiliá-lo a musicar a Missa Alemã. ${ }^{29}$ Lutero tinha uma concepção muito clara de que missa ele queria. Para ele "a música tem que centrar todas as suas notas e seus cantos no texto. A música evangélica tinha que estar a serviço do texto, tinha que "carregar' o texto". ${ }^{30}$ Além disso, as palavras de Cristo deveriam ter destaque na composição.

Com a Formula Missae, temos, então, uma missa em latim depurada dos elementos sacrificiais, como proposta de culto, em Wittenberg, em 1523. Mesmo assim, havia anseio por um pouco mais de reforma na forma, não só de pastores e comunidades, mas, inclusive, também do príncipe-eleito da saxônia. ${ }^{31}$ A Missa alemã foi definitivamente introduzida em Wittenberg no natal de 1525 e o texto foi precedido por um prefácio no qual Lutero acentua que a ordem não podia ser vista como lei, mas sim usada a partir do princípio da liberdade cristã, zelosa para com as pessoas simples e a juventude. ${ }^{32}$

Não defende a ideia de que toda a Alemanha deve assumir a ordem de Wittenberg; sua intenção é a de que haja uniformidade dentro dos diversos territórios. Essa uniformidade é necessária por causa do povo simples e da juventude. A ordem de culto é importante para o exercício e para a instrução na Palavra de Deus; é funcional, não é lei nem deve ser usada para se conseguir mérito diante de Deus. ${ }^{33}$

\footnotetext{
${ }^{27}$ LUTERO, M., Ao em Cristo venerável Nicolau Hausmann, p. 175-176.

${ }^{28}$ LUTERO, M., Ao em Cristo venerável Nicolau Hausmann, p. 173.

${ }^{29}$ DREHER, M., Missa Alemã e Ordem do Culto 1526, p. 174.

${ }^{30}$ DREHER, M., Missa Alemã e Ordem do Culto 1526, p. 174.

${ }^{31}$ DREHER, M., Missa Alemã e Ordem do Culto 1526, p. 174.

${ }^{32}$ DREHER, M., Missa Alemã e Ordem do Culto 1526, p. 175.

${ }^{33}$ DREHER, M., Missa Alemã e Ordem do Culto 1526, p. 175.
} 
No prefácio, na terceira linha, Lutero dirá: “de modo algum, façam dela uma lei compulsória, nem comprometam ou prendam a consciência de ninguém, mas façam uso da liberdade cristã segundo o seu agrado, como, onde, quando e por quanto tempo as circunstâncias o reclamem e exijam". ${ }^{34}$ Lutero tinha consciência de que a Missa Alemã se destinava a gente de pouca fé, gente muito simples que assistia ao culto, mas pouco ou nada entendiam do Evangelho. Isso o convenceu da necessidade do uso da língua alemã, como forma de promover a fé e conquistar pessoas para a fé evangélica.

Isso, porém, está sendo feito principalmente por causa da gente simples e da juventude, que deve e precisa ser treinada e educada diariamente na Escritura e na Palavra de Deus, para que se habituem com a Escritura, saibam manuseá-la, sejam versados e instruídos nela, para que saibam defender sua fé e, com o tempo, possam ensinar os outros e contribuir para o avanço do Reino de Cristo; por causa dessas pessoas é preciso ler, cantar, pregar, escrever e compor [versos], e se para esse fim fosse necessário e adiantasse alguma coisa, eu mandaria bater todos os sinos e tocar todos os órgãos e fazer soar tudo que possa soar. ${ }^{35}$

Interessante que Lutero não entende a MissaAlemã como uma substituição da Formula Missae "esta eu não quero ter revogado nem modificado como presente [escrito]", ${ }^{36}$ e que tem a função de preservar o latim e a tradição da Igreja. A Missa Alemã tem a função de falar mais próximo dos leigos sem instrução: "a maioria fica assistindo sem entender". ${ }^{37}$

Já na descrição sobre a missa, Lutero ressalta o que ele entende como essencial no culto:

Como em todo culto, o elemento mais importante é a pregação e o ensino da Palavra de Deus, procederemos, no tocante ao pregar e ler, do seguinte modo: no dia santo ou no domingo, manteremos as epístolas e os evangelhos habituais, como três prédicas. De manhã cedo, às 5 ou 6 horas, cantam-se vários salmos para as matinas. Em seguida, prega-se sobre a epístola do dia, principalmente em função da criadagem, para também seja atendida e ouça a Palavra de Deus [...]. Em seguida uma antífona e o Te

\footnotetext{
${ }^{34}$ LUTERO, M., Missa Alemã e Ordem de Culto 1526, p. 177.

${ }^{35}$ LUTERO, M., Missa Alemã e Ordem de Culto 1526, p. 178.

${ }^{36}$ LUTERO, M., Missa Alemã e Ordem de Culto 1526, p. 178.

${ }^{37}$ LUTERO, M., Missa Alemã e Ordem de Culto 1526, p. 179.
} 
Deum Laudamus ou o Benedictus alternadamente, com um Pai nosso, [oração de] coleta e Benedicamus Domino. Durante a missa das oito ou nove prega-se o Evangelho, conforma a época do ano. À tarde, durante as vésperas, antes do Magnificat, prega-se o Antigo Testamento na ordem sequencial..$^{38}$

A concepção da Missa Alemã, como o próprio nome diz, é eucarística. Ou seja, Lutero restaura a celebração da Ceia do Senhor em todos os cultos principais. Dentro do princípio da liberdade, ele preserva as vestes e os espaços litúrgicos, com mudanças discretas, mas de significado profundo, como, por exemplo, a posição do celebrante:

Aqui continuamos a utilizar as vestes litúrgicas, o altar e as velas, até acabarem, ou até que queiramos fazer uma modificação; entretanto, quem quiser proceder de outra maneira nesse ponto, não nos opomos. Porém, na missa genuína, exclusivamente entre cristãos, o altar não deveria permanecer da forma atual, e o sacerdote deveria voltar-se sempre para o povo como, sem dúvida, Cristo fez na Ceia. Bem, isso pode esperar para o tempo oportuno. ${ }^{39}$

Como podemos perceber, Lutero, mesmo tendo proposto duas ordens litúrgicas, a Formula missae et communionis (Formulário da missa e da comunhão) de 1523 e a Deutsche Messe (Missa Alemã) de 1526, estava muito mais preocupado em conservar a missa, fazendo as mudanças litúrgicas necessárias e oferecendo princípios para a confecção e validade de ordens litúrgicas, sendo que a doutrina da justificação funcionava como base principal.

Quais seriam estes princípios? (1) a liberdade evangélica ("não façam da ordem litúrgica uma lei compulsória, nem comprometam ou prendam a consciência de ninguém"), que encontra seu limite (2) no amor ("nos casos, portanto, em que as pessoas se escandalizam ou ficam confusas com toda a diversidade de práticas, temos efetivamente o dever de restringir a liberdade"). Acrescentam-se a estes (3) a unidade ("mas seria muito recomendável que em cada região o culto fosse celebrado de modo uniforme, e que os lugarejos e as aldeias circunvizinhos procedessem da mesma forma como a cidade mais próxima") e (4) ordem ("é algo exterior", "nenhuma ordem vale ou vigora por

${ }^{38}$ LUTERO, M., Missa Alemã e Ordem de Culto 1526, p. 182.

${ }^{39}$ LUTERO, M., Missa Alemã e Ordem de Culto 1526, p. 184. 
si mesma, (...) mas a vida, o mérito, a força e a virtude de todas as ordens está no uso adequado")..$^{40}$ Liberdade, amor, unidade e ordem são, pois, princípios para o culto evangélico.

Podemos, assim, concluir que para Lutero as suas propostas de reforma do culto e da liturgia tinham uma coerência muito grande com sua teologia. A compreensão da doutrina da justificação por graça, irá marcar o culto no sentido de dizer que é Deus, em Cristo, que nos serve no culto. É Deus que, sempre de novo nos dá algo no culto, o que acaba com a compreensão sacrificial da Eucaristia ou a compreensão de transubstanciação dos elementos da ceia. Culto e Eucaristia não são algo que se faz para Deus, mas algo que se recebe do próprio Deus. Da mesma forma, a compreensão que Lutero terá da fé, terá profundas implicâncias para o culto. A função principal do culto é despertar e manter a fé das pessoas no e a partir do Evangelho, no e a partir de Cristo. Fé não é algo que o ser humano faz, mas, dentro da mesma dinâmica da justificação por graça, é algo que Deus opera em nós através do Espírito Santo. Essa compreensão está profundamente marcada pela compreensão de Palavra de Deus, uma vez que a fé só pode ser despertada por meio da proclamação da Palavra. Esta proclamação ocorre no culto, através da pregação pura e correta ministração dos sacramentos. A Palavra, que é Cristo, é sempre presença viva e real no culto, seja na pregação, seja nos sacramentos. Nessa mesma frequência, a música assume para Lutero papel fundamental no culto. A música propaga o Evangelho.

\section{O Culto Cristão no Contexto Brasileiro 500 anos depois}

O Brasil tem a idade da Reforma Protestante. Em nossos pouco mais de 500 anos de história como país, ainda predominam entre nós profundos problemas sociais e políticos, agravados pelo imenso abismo social existente. Semelhantes ao período da Reforma, o poder e as riquezas estão concentrados nas mãos de poucos, enquanto a maioria da população vive sem acesso às mínimas oportunidades para usufruir os bens sociais, materiais e culturais. Também semelhante à época da Reforma, por aqui há uma tendência de instrumentalização da religião como forma de controle e alienação de pessoas e grupos, através de promessas mágicas de resolução de problemas pessoais, coletivos e sócio-políticos.

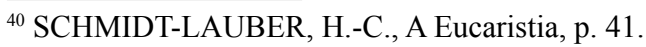


Nesse cenário, o culto torna-se a manifestação litúrgica das mais variadas teologias e crenças com as mais diferentes finalidades, reunindo milhares de pessoas. Diante dessa realidade, perguntas importantes que se colocam são, por exemplo: em que medida o culto tem contribuído para uma efetiva transformação social em nosso contexto? Uma segunda pergunta é: em que medida os princípios que nortearam a Reforma e o seu culto podem contribuir para uma prática litúrgica hoje? Para responder a essas duas questões, apresenta-se os seguintes pontos.

O culto cristão sempre é serviço de Deus em favor do ser humano caído e necessitado. Toda a liturgia nada mais é do que uma resposta à ação livre, dinâmica e graciosa de Deus em favor da pessoa, da comunidade e da Igreja. O mesmo movimento de Jesus Cristo em direção ao ser humano, a justificação por graça por meio da cruz, é o movimento que cada culto de novo rememora e revive. Em cada culto, Cristo nos serve com sua cruz e nos justifica por meio da fé. No Livro de Culto da Igreja Evangélica de Confissão Luterana no Brasil (IECLB), 500 anos depois e a 10 mil km de distância de Wittenberg, no sul do planeta, irá referir, exatamente, esse princípio, quando define o culto cristão.

Culto é aqui concebido como encontro que congrega Deus e um grupo de pessoas, bem como estas entre si. O sujeito do culto é Deus. Deus vem ao encontro da comunidade (Mt 18,20), e Deus de fato ordena que o culto aconteça (1Cor 11,24-25: "fazei isto"). O encontro é ação de Deus. As pessoas reagem e aceitam o convite de Deus. Nesse encontro, elas ouvem sua vontade (Palavra de Deus), comungam na sua mesa (Ceia do Senhor) e realizam comunhão entre si. A Deus dirigem oração, adoração, louvor, evidenciam sua disposição de assumir o compromisso da fé, e saem do culto para testemunhar a fé e para servir ao Senhor no contexto em que estão inseridas. ${ }^{41}$

Num contexto onde os cultos têm tantos protagonistas, pastor tal e igreja tal, cultos onde a comunidade e as pessoas precisam fazer sacrifícios em forma de ofertas ou aquisição de "bens sagrados" para conquistar algo diante de Deus e diante da vida, o princípio de Lutero coloca um critério muito claro para definirmos o que seja culto evangélico.

Culto cristão é sempre criatura da viva e dinâmica Palavra de Deus. Na dinâmica entre Lei e Evangelho, cada culto atualiza a Palavra de Deus,

${ }^{41}$ IECLB, Livro de Culto, p. 13. 
mostrando ao ser humano e à comunidade reunida a impossibilidade de se achegar até Deus e sua salvação, ao mesmo tempo, que proclama a ação de Cristo em nossa direção. O próprio Evangelho é o critério, ou seja, aquilo que promove a Cristo. Também neste aspecto, percebemos muitos abusos no nosso contexto, de cultos que são muito mais um arremedo da Palavra de Deus, nas palavras humanas, em forma de leis e regras, moralismo, fundamentalismo. Isso irá transparecer de forma muito clara no sermão de Lutero por ocasião da inauguração e consagração da igreja do Castelo de Torgau, em 1544, a conhecida Fórmula de Torgau. Referindo ao tempo e ao culto, Lutero assim dirá: "Que ali nada mais tenha lugar além da fala do nosso amado Senhor a nós por intermédio da sua Santa Palavra e da nossa resposta a ele em oração e louvor". ${ }^{42}$

Com base em Lutero, a função do culto evangélico não é outra que despertar e fortalecer a fé da comunidade. Este parece um elemento importante a ser relembrado. Não existe outro objetivo do culto por mais nobre que seja, como juntar gente, levantar uma oferta, emocionar, engajar na diaconia e no serviço social, dar recados ou disciplinar a moral. Culto evangélico se alimenta da fé em Jesus Cristo, o Senhor da Igreja, e está totalmente voltado para a manutenção e o cuidado desta fé e suas consequências no ministério do amor ao próximo.

Culto evangélico não nasce do gosto do pastor e de impulsos estéticos de pessoas e movimentos isolados, mas deixa-se moldar a partir da vasta e rica tradição da Igreja. A reforma do culto é uma reforma conservadora e crítica, ao mesmo tempo, de forma que o culto evangélico está sempre com um pé no passado e um pé no presente. Conservadorismo e crítica são quase um paradoxo para entender o culto luterano. "A abordagem luterana da liturgia afirma o paradoxo de uma tradição mantida de forma inabalável junto com uma crítica evangélica igualmente inabalável". ${ }^{43}$ Trata-se de fato de uma "reforma" da missa desde a teologia da justificação por graça e fé. Isto permite ao mesmo tempo um criticismo conservador e um conservadorismo crítico, algo difícil de ser entendido pela ala mais esquerda da liturgia (White), a qual busca romper com a tradição católica da missa. Lathrop observa que este não é o único paradoxo da Reforma: Lei e Evangelho, os dois reinos, criação e redenção, simultaneamente justo e pecador, este homem é Deus e este pão

\footnotetext{
${ }^{42}$ VOLP, R., Liturgik, p. 736.

${ }^{43}$ LATHROP, G. W., O culto no contexto luterano, p. 220.
} 
é o corpo de Cristo, são outros exemplos que compõem o acervo teológico luterano. ${ }^{44}$

Os riscos deste paradoxo é tornar a tradição mera teimosia do "fazer do jeito que sempre fizemos", ou ainda um apego à tradição imprimida pela Reforma, como se o culto luterano, que na maioria das vezes se restringe a uma forte acentuação da Palavra lida e pregada, como longos exercícios didáticos restritos ao pregador, como uma tendência. Dizer isso não significa dizer que o culto está estagnado na tradição, no tempo e no espaço. O culto é sempre evento inculturado, resultado da Palavra encarnada (texto do Wainwright), em diálogo com os desafios, linguagens e costumes presentes no local e no tempo nos quais as comunidades celebram.

$O$ culto evangélico é ação de graças em forma de celebração, alegria, louvor e música. Para Lutero a Frau Música é uma criatura divina - seja ela música sacra ou profana. Para ele, porém, a música só alcança a verdadeira realização de seu sentido quando relacionada com Cristo e o cantar é uma consequência natural da fé. A música no culto é um estímulo para outras pessoas se ocuparem com a fé.

A música é uma esplêndida dádiva de Deus e eu gostaria de exaltá-la com todo o meu coração e recomendá-la a todos. Mas eu estou tão dominado pela diversidade e magnitude de suas virtudes e benefícios que (...), por mais que eu queira exaltá-la, minha exaltação será insuficiente e inadequada (...). Se queres confortar os tristes, aterrorizar os felizes, encorajar os desesperados, tornar humilde os orgulhosos, acalmar os inquietos ou tranquilizar os que estão tomados por ódio (...) que meio mais efetivo do que a música poderias encontrar? ${ }^{45}$

Para os reformados, a música será uma forma não só de louvor, mas também de proclamação da Palavra de Deus. "A Palavra de Deus está sendo oferecida de modo tão lúcido e claro em pregação, canto, fala e pintura, que eles [reis, príncipes e senhores] têm que admitir que é a verdadeira Palavra de Deus". ${ }^{46}$ Ele entende, assim como era entendido na Idade Média, que a música é a própria liturgia. "Deixe que as entonações das missas do domingo e das vespertinas sejam conservadas; elas são muito boas e procedem das

\footnotetext{
${ }^{44}$ LATHROP, G. W., O culto no contexto luterano, p. 220 s.

${ }^{45}$ SCHALK, C. F., Lutero e a música, p. 8.

${ }^{46}$ SCHALK, C. F., Lutero e a música, p. 48.
} 
Escrituras". ${ }^{47}$ Para ele, porém, não apenas o clero e coro deve cantar a liturgia, mas, sim, todo o povo, como um verdadeiro exercício do sacerdócio geral de toda a pessoa batizada. ${ }^{48} \mathrm{O}$ culto assume para Lutero o espaço privilegiado de experimentar a viva Palavra de Deus e, em reação a ela, louvar a Deus pela sua imensa graça, sendo a música a principal forma desse louvor. "Deus não exige grandes sacrifícios ou tesouros preciosos e caros pelas suas bênçãos. Não, Ele pede pela mais fácil, isto é, canto e louvor" ${ }^{49}$ Ou como dirá em outro comentário, falando do sacrifício de louvor: "O culto do Novo Testamento (...) nada mais é do que canto, louvor e agradecimento. Este é um canto singular. Deus não quer nossos sacrifícios e obras. Ele está satisfeito com o sacrifício do louvor". 50

São elementos importantes para pensar a música no culto hoje, como uma forma de proclamação da Palavra de Deus, do Evangelho; resposta da comunidade como expressão de louvor e da fé; o protagonismo da comunidade na música do culto; a continuidade com a vasta, diversa e ampla tradição da igreja, elementos em clara oposição ao mercado gospel brasileiro.

Não por último, culto evangélico não é para indivíduos, mas sim, evento público e comunitário que transforma politicamente a sociedade e o mundo. O culto não pertence ao pastor, mas sim a sua comunidade. A comunidade não assiste o culto, mas sim o celebra, de forma que toda a vida da comunidade, suas glórias e suas cruzes moldam a liturgia do culto e deixam-se impulsionar e questionar pelo culto. Por isso, culto evangélico, está do prelúdio até o poslúdio totalmente comprometido com a transformação política, social e cultural do contexto por meio da voz viva do Evangelho.

\section{Conclusão}

Essa breve revisão sobre os princípios da reforma da missa feita por Martin Lutero, lança luz sobre a reflexão litúrgica no contexto brasileiro, não só nas igrejas oriundas da Reforma, mas também para aquelas igrejas que ousam se manter fiéis ao princípio evangélico. Isso significa, em primeiro lugar, preservar em nossos cultos a centralidade daquilo que Deus sempre de novo faz através de Cristo em favor do ser humano caído e necessitado. Para

\footnotetext{
${ }^{47}$ SCHALK, C. F., Lutero e a música, p. 52.

${ }^{48}$ SCHALK, C. F., Lutero e a música, p. 39ss.

${ }^{49}$ SCHALK, C. F., Lutero e a música, p. 49.

${ }^{50}$ SCHALK, C. F., Lutero e a música, p. 49.
} 
tal, o culto cristão se alicerça na Palavra de Deus - Palavra e Sacramento -, meio através do qual a fé é despertada e mantida. Por causa da ação de Deus, no e através do culto, a comunidade reage com seu louvor, sua oração, sua ação ministerial no mundo. Quando olhamos para a reforma da missa de Lutero, também redescobrimos que os meios através dos quais a comunidade encontra a sua expressão litúrgica estão dispostos ao longo da vasta tradição da Igreja. Ou seja, o culto cristão não é uma construção a partir do gosto ou das tendências, mas se deixa tecer a partir da tradição bíblica, litúrgica e eclesiástica. E, mesmo assim, o culto cristão não está preso à tradição antiga, mas sim, é expressão viva, alegre, festiva, profética, musical de comunidades que vivem em culturas e sociedades de hoje. O culto se incultura na vida da comunidade de hoje e, por ter sua fonte primeira em Cristo, o culto evangélico impacta vidas, transforma contextos, toma posição política em favor da justiça e da paz de toda a criação. Não da paz e da justiça desse mundo, mas da paz e da justiça que só Cristo pode dar, para a glória de Deus.

\section{Referências bibliográficas}

BRAND, E. (Ed.). A liturgia entre os luteranos. Genebra: FLM; São Leopoldo: CEM, 1985.

BUSS, P. W. (Org.). Lutero e o culto cristão. Porto Alegre: Concórdia, 2011. DREHER, M. Culto: Introdução ao assunto. In: LUTERO, M. Obras Selecionadas. São Leopoldo: Sinodal; Porto Alegre: Concórdia, 2000. p. 153-154. v.7. DREHER, M. Formulário da Missa e da Comunhão para a Igreja de Wittenberg 1523: Introdução. In: LUTERO, M. Obras Selecionadas. São Leopoldo: Sinodal; Porto Alegre: Concórdia, 2000. p. 155-156. v.7.

DREHER, M. Missa Alemã e Ordem do Culto 1526: Introdução. In: LUTERO, M. Obras Selecionadas. São Leopoldo: Sinodal; Porto Alegre: Concórdia. p. 173-177. v.7.

DREHER, M. N. Igreja, Ministério, Chamado e Ordenação. São Leopoldo: Sinodal; Porto Alegre: Concórdia, 2011.

FEDERAÇÃO LUTERANA MUNDIAL. Declaração de Caracas sobre liturgia. São Leopoldo: CEM, 1989.

FEDERAÇÃO LUTERANA MUNDIAL. O culto luterano: material de estudo. São Leopoldo: Sinodal, 1982.

HAHN, C. J. História do culto protestante no Brasil. São Paulo: ASTE, 1989. 
HOFFMANN, M.; BEROS, D.; MOONEY, R. (Eds.). Radicalizando a Reforma: outra teologia para outro mundo. São Leopoldo: EST / Sinodal, 2017. IGREJA EVANGÉLICA DE CONFISSÃO LUTERANA NO BRASIL. Livro de Culto. São Leopoldo: Sinodal, 2003.

KIRST, N. Rudimentos de Homilética. São Leopoldo: Sinodal / IEPG, 1985.

LATHROP, G. W. O culto no contexto luterano. In: SCHMIDT-LAUBER, H.C. et al. Manual de Ciência Litúrgica. São Leopoldo: EST / Sinodal, 2011. p. 104-135. v.1.

LUTERO, M. A Ordem do Culto na Comunidade 1523: Introdução. In: LUTERO, M. Obras Selecionadas. São Leopoldo: Sinodal; Porto Alegre: Concórdia, 2000. p. 65-69. v.7.

LUTERO, M. Ao em Cristo venerável Nicolau Hausmann, Pastor da igreja de Zwickau. In: LUTERO, M. Obras Selecionadas. São Leopoldo: Sinodal; Porto Alegre: Concórdia, 2000, p. 156-172. v. 7.

LUTERO, M. Da Santa Ceia de Cristo - Confissão. In: LUTERO, M. Obras selecionadas. São Leopoldo: Sinodal; Porto Alegre: Concórdia, 1993. p. 217375. v.4.

LUTERO, M. Exortação ao Sacramento do Corpo e Sangue de Nosso Senhor. In: LUTERO, M. Obras selecionadas. São Leopoldo: Sinodal; Porto Alegre: Concórdia, 2000. p. 222-254. v.7.

LUTERO, M. Missa Alemã e Ordem de Culto 1526: Prefácio de Martinho Lutero - O culto. In: LUTERO, M. Obras Selecionadas. São Leopoldo: Sinodal; Porto Alegre: Concórdia, 2000. p. 177-205. v.7.

LUTERO, M. O Manual do Batismo Traduzido para o Alemão - Revisado 1526. In: LUTERO, M. Obras selecionadas. São Leopoldo: Sinodal; Porto Alegre: Concórdia, 2000. p. 209-221. v.7.

LUTERO, M. Sermões sobre os Sacramentos. In: LUTERO, M. Obras selecionadas. São Leopoldo: Sinodal; Porto Alegre: Concórdia, 2000. p. 399-424. v.1.

LUTERO, M. Um Sermão a respeito do Novo Testamento, Isto É, a respeito da Santa Missa. In: LUTERO, M. Obras selecionadas. São Leopoldo: Sinodal; Porto Alegre: Concórdia, 2000 p. 253-275. v.2.

LUTERO, M. Um Sermão sobre o Venerabilíssimo Sacramento do Santo e Verdadeiro Corpo de Cristo e Sobre as Irmandades. In: LUTERO, M. Obras selecionadas. São Leopoldo: Sinodal; Porto Alegre: Concórdia, 1987. p. 425-444. v.1. 
MARTINI, R. R. Eucaristia e conflitos comunitários. São Leopoldo: Sinodal, 2003.

RIETH, R. W. Lutero e o culto cristão. Tear: Liturgia em Revista, n. 9, p. 7-8, dez. 2002.

SCHALK, C. F. Lutero e a música: paradigmas de louvor. São Leopoldo: Sinodal, 2006.

SCHMIDT-LAUBER, H.-C. A eucaristia. In: SCHMIDT-LAUBER, H.-C.; BIERITZ, K.-H.; MEYER-BLANCK, M. (Eds.). Manual de Ciência Litúrgica. São Leopoldo: EST / Sinodal, 2011, p. 41. v.2.

SCHMIDT-LAUBER, H.-C.; BIERITZ, K.-H.; MEYER-BLANCK, M. (Eds.). Manual de Ciência Litúrgica: fundamentos do culto cristão. São Leopoldo: EST / Sinodal, 2011. v.1

SCHMIDT-LAUBER, H.-C.; BIERITZ, K.-H.; MEYER-BLANCK, M.(Eds.). Manual de Ciência Litúrgica: história e forma do culto. São Leopoldo: EST / Sinodal, 2013. v.2.

SCHMIDT-LAUBER， H.-C.; BIERITZ，K.-H.; MEYER-BLANCK，M. (Eds.). Manual de Ciência Litúrgica: ofícios casuais/A configuração do culto. São Leopoldo: EST / Sinodal, 2014. v.3.

SCHMIDT-LAUBER, H.-C.; BIERITZ, K.-H.; MEYER-BLANCK, M. (Eds.). Manual de Ciência Litúrgica: práticas especiais do culto cristão. São Leopoldo: EST / Sinodal, 2016. v.4.

VOLP, R. Liturgik: Die Kunst, Gott zu feier - Theorien und Gestaltung. Gütersloh: Gütersloher Verlaghaus, 1994. v.2.

WAINRIGHT, G. Fundamentação sistemático-teológica. In: SCHMIDT-LAUBER, H.-C.; BIERITZ, K.-H.; MEYER-BLANCK, M. (Eds.). Manual de Ciência Litúrgica. São Leopoldo: EST / Sinodal, 2011. p. 104-135. v.1.

Júlio Cézar Adam

Doutor em Teologia pela Universidade de Hamburgo Docente adjunto de Teologia Prática na Faculdades EST

São Leopoldo / RS - Brasil

E-mail: julio3@est.edu.br

Recebido em: 02/11/17

Aprovado em: 31/08/18 